\title{
ANOTASI BIBLIOGRAFI \\ PERANAN MEDIA PEMBELAJARAN SEJARAH DALAM MENUMBUHKAN SIKAP NASIONALISME
}

\author{
Oleh \\ Fathurrahman \\ Email: rfathur235@gmail.com \\ Program Studi Pendidikan Sejarah Fakultas Keguruan dan Ilmu Pendidikan \\ Universitas Lambung Mangkurat \\ Banjarmasin
}

Susanto, H., \& Akmal, H. (2019). Media Pembelajaran Sejarah Era Teknologi

Informasi (Konsep Dasar, Prinsip Aplikatif, dan Perancangannya). Banjarmasin: FKIP ULM.

Buku ini membahas mengenai media pembelajaran sejarah di era teknologi informasi. Adapun pokok pembahasan dalam buku ini antara lain konsep media pembelajaran sejarah, prinsip aplikatif pembuatan media pembelajaran sejarah berbasis teknologi dan cara merancang media pembelajaran sejarah berbasis teknologi informasi.

Syaharuddin \& Susanto, H. (2019). Sejarah Pendidikan Indonesia (Era Pra Kolonialisme Nusantara sampai Reformasi). Banjarmasin: FKIP ULM.

Buku ini membahas mengenai sejarah pendidikan yang terjadi sejak masa klasik hingga reformasi. Dalam buku ini pada bagian bab telah disusun secara sistematis sesuai dengan periodasi sejarah, dari masa Klasik, Kolonial, Era Kemerdekaan, Orde Lama, Orde Baru dan Reformasi.

Widiani, L.S., Darmawan, W., \& Ma'mur, T. (2018). PENERAPAN MEDIA FILM SEBAGAI SUMBER BELAJAR UNTUK MENINGKATKAN KEMAMPUAN MENGOLAH INFORMASI SISWA DALAM PEMBELAJARAN SEJARAH. Factum: Jurnal Sejarah dan Pendidikan Sejarah, 7(1), 123-132.

Artikel ini membahas mengenai kemampuan peserta didik dalam hal mengolah informasi sejarah melalui media film. Dalam artikel ini dilakukan IV tahapan. Tahapan I berupa perijinan dengan pihak sekolah dan guru, tahapan II mempersipakan kegiatan pembelajaran seperti RPP, instrument, dll. Tahapan III berupa perangkat pembelajaran yang digunakan. Tahapan IV berupa implementasinya. 
Syaharuddin., Winarso, H. P., \& Al-Hidayatullah. (2019). NILAI-NILAI NASIONALISME PERJUANGAN HASSAN BASRY SEBAGAI SUMBER BELAJAR SEJARAH. Historia: Jurnal Pendidikan dan Penelitian II(2), 91-96.

Artikel ini membahas mengenai nilai-nilai nasionalisme perjuangan dari pahlawan nasional Kalimantan Selatan Brigjend. TNI (Purn) H. Hasan Basry pada awal kemerdekaan hingga mengikrarkan "Proklamsi 17 Mei" dengan menolak pembentukan Negara Kalimantan dan tetap setia terhadap NKRI.

Mardiani, F. (2018). PENGEMBANGAN MEDIA PEMBELAJARAN SEJARAH LOKAL BERBASIS AUDIO VISUAL CORAK KAIN SASIRANGAN DI SMAN 5 BANJARMASIN. ISTORIA: Jurnal Pendidikan dan Sejarah, 4(1), 1-10.

Artikel ini membahas mengenai media pembelajaran sejarah berupa video pembelajaran berbasis corak kain sasirangan yang memberikan sebuah pengaruh terhadap nilai prestasi dari peserta didik. Penelitian ini menggunakan Uji T.

\section{Simpulan Konseptual dan Anotasi Bibliografi}

Media pembelajaran ialah sebuah teknologi aplikasi ilmu pengetahuan berupa media elektronik yang memberikan kemudahan dan memperlancar dalam proses pembelajaran, terutama dimasa pandemi saat ini. Pembelajaran sejarah ialah sebuah proses interaksi yang dilakukan peserta didik dengan lingkungannya, hingga terjadi sebuah perubahan tingkah laku yang disebabkan dari interaksinya dengan mempelajari sejarah. Belajar sejarah tidak hanya mengenai hafalan maupun mengenai peristiwa-peristiwa yang pernah terjadi pada masa lalu, melainkan mengenai bagaimana peserta didik mampu mengembangkan kemampuannya dalam berpikir secara kronologi dalam memahami dan menjelaskan mengenai proses perkembangan dan perubahan yang terjadi pada masyarakat dengan keanekarangaman sosial budaya dalam rangka untuk menemukan jati diri bangsa, serta bisa meningkatkan jati dirinya sebagai suatu bagian dari suatu bangsa Indonesia. Dalam hal ini, mempelajari sejarah sangatlah penting, karena dari sejarah kita bisa mengetahui masa lalu yang pernah terjadi pada bangsa kita.

Nasionalisme ialah sebuah sikap kecintaan terhadap bangsa dan Negara. Untuk meningkatkan kecintaan tersebut tentunya harus mengetahui terlebih dahulu hal apa saja yang pernah terjadi pada bangsa itu. Tanpa mengetahui sejarahnya, tentunya akan kesulitan untuk mencintai bangsa dan negaranya. Seperti halnya jargon yang pernah diutarakan oleh presiden pertama Republik Indonesia bapak Ir. Soekarno "Jangan sekali-kali Melupakan Sejarah". 